\title{
The Open Methods of Coordination as Amplifier for EU Soft Law:
}

\section{The case of EU Youth Policy}

\author{
By Paul Copeland* and Beryl ter HaAR**
}

\begin{abstract}
The legally non-binding nature of the EU's Open Method of Coordination (OMC) has sparked a lively scholarly debate that includes, amongst other things, research about its function and effectiveness in conjunction with hard law and the integration capacity created by different governance structures (hybridity). This paper contributes to this debate via an analysis of EU integration within the field of Youth Policy. Contrary to existing research that examines hybrid structures in which the OMC interacts with hard law, EU Youth Policy has developed a hybrid structure in which the OMC mainly interacts with soft law. Our conclusion is that the developed hybrid structure has resulted in an incremental and coherent EU Youth Policy in which the OMC plays a crucial role.
\end{abstract}

Keywords: theory of hybridity, OMC, new governance, soft law, EU Youth Policy

\section{INTRODUCTION}

As a legally non-binding mode of new governance, the EU's open method of coordination (OMC) has sparked a lively scholarly debate with respect to its functioning as a European integration instrument ${ }^{1}$ and its effectiveness in creating policy change within the Member States. ${ }^{2}$ Current approaches to analysing the OMC usually examine it in isolation of other EU governance tools, however, "the OMC is one among a panoply of different instruments" to govern an EU policy field. In response, the theory of hybridity acknowledges the coexistence and engagement of hard law and new modes of governance (particularly the $\mathrm{OMC}$ ) and explores their interaction.

Despite this theoretical acknowledgement, existing studies have two limitations: first, only a few empirical case studies have been conducted in exploring the theory of hybridity; and second, such studies are limited to the interaction of new governance (the OMC) with hard law. ${ }^{4}$ The latter is particularly significant given that EU policy fields are governed by a wide range of instruments including hard law (regulations and directives), new governance

1 Jonathan Zeitlin, Philippe Pochet and Lars Magnussen (eds), The Open Method of Coordination in Action (Peter Lang 2005).

2 Martin Heidenreich and Jonathan Zeitlin (eds), Changing European Employment and Welfare Regimes (Routledge 2009).

${ }^{3}$ Caroline de la Porte and Philippe Pochet, 'Introduction', in Caroline de la Porte and Philippe Pochet (eds), Building Social Europe through the Open Method of Co-ordination (Peter Lang 2003) 1.

4 Gráinne de Búrca and Joanne Scott, Law and New Governance in the EU and the US (Hart Publishing 2006).

*Lecturer in Public Policy, Queen Mary University London.

**Lecturer in European and International Labour Law, University of Amsterdam, b.p.terhaar@uva.nl. 
(OMC) and traditional soft law (e.g. action programmes, recommendations and resolutions). Consequently the current theory of hybridity and its empirical case studies provide a narrow understanding of EU governance and the interaction of its various components. The focus on hard law, the OMC, and their interaction, constructs a dichotomy in which the OMC and thereby all EU soft law are considered to be relatively weak. However, this may turn out to be different, when the interaction between all these instruments (hard law, the OMC and soft law) is taken into account. In particular, this may be the case in policy areas in which there is little or no governance via hard law and mainly governance via the OMC and traditional soft law.

Therefore, the aim of this paper is to examine the function of the OMC as an integration instrument by its interaction with the broad range of EU governance instruments, including hard law and soft law. For this we focus on the field of EU Youth Policy - a policy field which is identified, in part, as being governed by the OMC. ${ }^{5}$ EU Youth Policy is particularly interesting because it is one of the seven flagship initiatives within the Europe 2020 Strategy.

This paper is structured as follows: the first section explains the theory of hybridity. In comparison to the existing theory, we argue that it is possible to conceive hybridity much more broadly to include a wider range of EU integration instruments. Sections two and three concern the case study of the paper - EU Youth Policy - to demonstrate the hybridity of the OMC with hard law and more significantly soft law. Section two historically analyses the development of EU Youth Policy, while Section three provides an inventory and an analysis of the integration instruments utilised to govern EU Youth Policy. From these two sections we are able to determine how the instruments have interacted over time within the policy field. The final section reflects on what the hybrid structure within EU Youth Policy implies for the integration capacity of the OMC in this particular field. Integration capacity in this context is understood as being able to influence Member States' domestic policies. In this paper this is measured by the positive and negative incentives that are created by the use of the OMC as the main driver to further EU integration within EU Youth Policy.

\section{HYBRIDITY AND METHODOLOGY}

\section{Gap-thesis and theory of hybrid structures}

As a new governance instrument, the OMC has been conceptualised in terms of the gapthesis, which provides an explanation for the development of patterns of new governance. It argues that formal mechanisms of regulation are either blind or unable to deal with: the changing practice of governance that includes the participation of the affected actors (stakeholders); the emphasis on transparency and policy learning; and ongoing evaluations and reviews. ${ }^{6}$ In fact, this blindness not only applies to hard law, but also to traditional EU soft law. ${ }^{7}$ In response, the emergence of new modes of governance is an attempt to address some of the failings of traditional modes of governance and can be distinguished from both

5 Brigid Laffan and Colin Shaw, 'Classifying and Mapping the OMC in Different Policy Areas' (2005) paper 02/D09 NEWGOV - New Mode of Governance 14.

6 De Búrca and Scott 4.

7 Susanna Borrás and Keneth Jacobsson, 'The Open Method of Co-ordination and New Governance Patterns in the EU’ (2004) 11/2 Journal of European Public Policy 185. 
traditional hard and soft law. The EU's OMC is argued to be archetypical of these new modes of governance.

While the gap-thesis provides an explanation as to why new forms of governance have emerged, the theory of hybrid structures aims to provide a better understanding of how these forms of new governance coexist and thereby interact in a policy area with mainly traditional hard law. In this respect Trubek and Trubek distinguish between three varieties of coexistence, i.e. situations in which new governance and hard law operate in the same policy domain. ${ }^{8}$ Thus, when new governance and hard law simultaneously operate towards a common objective, but they have not merged together, they are complementary. When newer forms of governance are designed to perform the same task as legal regulation and are thought to do it better, or there appears to be a necessary choice between the two, they are rivalry. They are transformative if a configuration is not only complementary, but also integrates into a single system in which the functioning of each element is necessary for the successful operation of the other. Furthermore, Trubek and Trubek note that hybrid structures can be consciously designed to get the best policy outcome of new governance and hard law. ${ }^{9}$ Hybrid structures can also gradually grow into a complementary structure or merge into a new constellation. Sometimes this is done intentionally to displace older forms of governance, but it can also occur unintentionally as new governance patterns make it hard to deploy existing modes of governance. In this particular constellation the new and older forms of governance coexist as rivals. Hybrid forms of governance can have important implications for the success or failure of a policy area. In this respect, Trubek and Trubek give as examples the successful coexistence of new governance (e.g. the OMC) and hard law in the Green Tier Policy of Wisconsin and the failed coexistence of the EU's Stability and Growth Pact. ${ }^{10}$

In summary, the theory of hybridity is about how two or more European integration governance instruments interact with each other. Despite this, within the current literature there has been an emphasis on analysing the interaction between the OMC and hard law, but in practice EU policy areas are governed by a variety of instruments, including the OMC, hard law and soft law. Secondly, what Trubek and Trubek do not directly address, but which is also significant for hybrid structures, is the overall capacity of a hybrid structure to create incentives for Member State engagement and activity. From this perspective, we argue that both the integration capacity and the incentives for Member States to engage in a policy area are stronger when the governance instruments interact positively, either by complementarity or transformation, and are weaker when the governance instruments compete for dominance. We therefore argue that to fully capture the integration capacity of a policy field, it is necessary to determine the interaction structure of all instruments involved in a policy area. Therefore an analysis of a policy area requires this broader scope and the following three hybrid structures can be defined:

- complementarity: two or more integration instruments working for common goals,

- rivalry: two or more integration instruments competing for dominance,

- transformation: two or more instruments merge into a new hybrid process.

${ }^{8}$ David M. Trubek and Louise Trubek, 'New Governance and \& Legal Regulation: Complementarity, Rivalry, and Transformation’ (2007) 13/3 Columbian Journal of European Law 543.

9 ibid.

10 ibid 557-558. 
This broadens the scope of the theory to the whole range of EU integration instruments, hence it enables the study of the interaction of similar integration instruments - for example, two directives, two action programmes or two OMCs. Broadening the theory of hybridity is particularly relevant to the increasing tendency within the EU to coordinate governance. ${ }^{11}$

\section{Methodology of defining hybrid structures}

In this paper we apply the broader theory of hybridity to the field of EU Youth policy. This field is interesting since it is a policy that is governed by the OMC and represents a policy area that is currently silent in the EU. The analysis of the hybrid structure of EU Youth Policy is done in two stages: firstly, the historical development of EU Youth Policy; and secondly, an analysis of its legal instruments.

The historical development of EU Youth Policy unpacks the current policy mix within the EU. The historical analysis is indicative of how the governance framework has evolved, but it does not provide an overview of the actual instruments - which create the incentives - involved within EU Youth Policy. In the second stage of our analysis we identify the instruments operationalised within EU Youth Policy. Since we are concerned with EU integration instruments, we selected only those instruments that address the Member States directly. Therefore, the opinions of the European Parliament, the Green and White Papers of the Commission and the Presidency Conclusions of the European Council were all excluded.

The identified instruments are ordered by the type of instrument (directive, action programme, resolution, OMC, etc.), analysed for the policy action they address, and put into chronological order. Such an overview is necessary to identify which instruments are currently involved with EU Youth Policy and therefore need to be analysed on the hybrid structure they create, which is the subject of the final section of the paper. To identify the type of hybrid structure that is created we analyse how the instruments interact with each other, with the OMC in the centre, since we are interested in the function of this instrument in particular.

Finally, an analysis is made of the incentives created by the instruments used to govern the area of youth. In general there are two ways by which the Member States are encouraged to take EU measures into account when developing their own policies: either by positive incentives or by compliance mechanisms. As for the positive incentives we identify three mechanisms: partial or full financial support; procedural or practical support of the EU; and support in learning or broadening knowledge. With respect to compliance we identify three mechanisms: the submission of progress or implementation reports by the Member States to the Commission; evaluation by the Commission; and judicial review by the European Court of Justice (ECJ).

Depending on the type of hybrid structure created by the framework resolution, these ways of influencing Member States either weaken each other (when rivalry) or strengthen each other (when complementary or merged by transformative hybridity).

\section{HISTORICAL DEVELOPMENT OF EU YOUTH POLICY}

When tracing the subject of youth in EU treaties, we find the first official reference in the 1957 EEC-Treaty. Article 50 of this treaty provides that Member States shall, within the

11 Keneth Armstrong, 'EU Social Policy and the Governance Architecture of Europe 2020' (2012) 18/3 Transfer: European Review of Labour and Research 285-300. 
framework of a joint programme, encourage the exchange of young workers. With the Treaty of Maastricht ${ }^{12}$ this provision was complemented with Article 126 TEC, which deals with youth and education and the participation of young people in democratic life in Europe. Although this seems to cover a broad scope, the competence to deal with the subject is limited to the encouraging of the cooperation between the Member States and, if necessary, by supporting and supplementing their action, while fully respecting the responsibility of the Member States for the content of teaching and the organisation of education systems and their cultural and linguistic diversity. More specifically within both provisions the competence is limited to supportive and supplementary measures. ${ }^{13}$ Thus, although the personal scope of the EU institutions with respect to young persons widened - from young workers only to youth in general - the material scope became smaller education - and the competence to deal with this became weaker since article 126 TEC gives the EU institutions no formal law-making powers. ${ }^{14}$ This has remained unchanged during the revisions of Amsterdam ${ }^{15}$ (article 149 TEC); Nice $^{16}$ (article 149 TEC); and Lisbon ${ }^{17}$ (article 165 TFEU).

It is in this formal context that EU Youth Policy developed during the 1990s when it gained political momentum at the transnational level. This began with the Commission's White Paper entitled Growth, Competitiveness and Employment, which drew attention to the issue of unemployment, including the issue of youth unemployment. ${ }^{18}$ In the Commission's 1994 White Paper 'European Social Policy', it was noted that "EU-wide youth unemployment stands at over $20 \%$, as against $13 \%$ in the US and $5 \%$ in Japan”. ${ }^{19}$ In response, the White Paper proposed a number of initiatives relating to the youth employment, and training and education - such as a Union-wide guarantee that noone under the age of 18 can be unemployed, the elimination of basic illiteracy for school leavers, and the improvement of education, training and vocational training. ${ }^{20}$ While many of these initiatives had already been addressed in action programmes and Council resolutions (see

\footnotetext{
12 Consolidated Version of the Treaty on European Union, Treaty of Maastricht [1992] OJ C $325 / 5$.

13 See Article 6 (education, vocational training, youth and sport) TFEU. Since Article 47 TFEU
} stipulates that the Member States shall, within a framework of a joint programme, encourage the exchange of young workers, the competence in this context is also limited to supportive and supplementary measures, rather than a shared competence as is more general within the provisions of the Internal Market.

14 Bettina Lange and Nafsika Alexiadou, 'New Forms of European Union Governance in the Education Sector? A Preliminary Analysis of the Open Method of Coordination’ (2007) 6/4 European Educational Research Journal 321.

15 Treaty of Amsterdam, Amending the Treaty of the European Union, the Treaties Establishing the European Communities and Certain Related Acts [1997] OJ L-2985.

16 Treaty of Nice, Amending the Treaty on European Union, the Treaties Establishing the European Communities and Certain Related Acts [2001] OJ C 80/01.

17 Treaty of Lisbon amending the Treaty on European Union and the Treaty Establishing the European Community [2007] OJ C306/01.

18 European Commission (1993) White Paper on Growth, Competitiveness, Employment: The Challenges and Ways Forward in the $21^{\text {st }}$ Century. COM (93) 700 Final.

19 European Commission (1994) European Social Policy - A Way Forward for the Union: A White Paper. COM (94) 333 final.

${ }^{20}$ Commission, 'EU youth report. An EU strategy for youth - Investing and empowering. Commission staff working document accompanying the Communication’ SEC (2009) 549 final, 17. 
next section), they were first coherently brought together within the two White Papers. Moreover, by bringing these initiatives together, the White Papers were able to make a significant difference in that they shifted the narrative of EU employment and social policy from one which concerned workers and the establishment and protection of their rights, to one in which unemployment and the increase of employment were to be the focus of attention; ${ }^{21}$ a shift that became tangible with the introduction of the European Employment Strategy (EES) in the Treaty of Amsterdam. Although not mentioned in the Treaty itself, the employment guidelines make it clear that the strategy also concerns youth policies.. ${ }^{22}$ In order to reduce youth unemployment, Member States are required to develop employment friendly strategies with the overall aim of ensuring "every unemployed young person is [to be offered] a new start before reaching six months of unemployment, in the form of training, retraining, work practice, a job or other employability measure". ${ }^{23}$ Member States are also required to ease the transition from school to work, particularly for young people from poor backgrounds. As such, they are required to improve the quality of their education systems, and where appropriate, develop apprenticeship training.

The inclusion of youth in the EES appears to be the beginning of a significant policy activism within the field of Youth Policy and its mainstreaming into other existing policies, among which are participation policies and social inclusion. Moreover, it denotes the emergence of a genuine EU Youth Policy that was broad in scope. For instance, on 8 February 1999 the European Council and the Ministers responsible for Youth adopted a resolution on youth participation that emphasised the importance of young people taking an active part in social, political, cultural and economic life, ${ }^{24}$ whilst on 23 November 1999 the Youth Council established guidelines including a cross-sectorial approach to youth questions and a policy based on involving young people. These were to underpin policy cooperation regarding youth and were supported by the European Council's Lisbon Strategy of March 2000 and the Laeken Declaration of December 2001. While the former offers a wider context for Youth policy, namely that of employment and social inclusion, both including education, the latter broadens the policy context by emphasising participation issues, the needs to increase employment and combat social exclusion across the EU, and the fostering of economic and social cohesion.

It is within this context that in 2001 a further step was taken towards developing an all-encompassing EU Youth Policy with the publication of the EU Commission's White Paper 'A New Impetus for European Youth'. ${ }^{25}$ The White Paper proposed the appointment of a national coordinator from each Member State as a Commission representative for youth-related issues. It outlined four priority areas: first, the introduction of new ways of enabling young people to participate in public life; second, the improvement of information on European issues for the young; third, to encourage voluntary service; and fourth, to increase the knowledge of youth-related issues. The White Paper also proposed to take the youth dimension into account much more thoroughly when developing other relevant

${ }^{21}$ Samantha Velluti, New Governance and the European Employment Strategy (Routledge 2010).

${ }^{22}$ European Council (1998) Council Resolution of 15 December 1997 on the 1998 Employment Guidelines. OJ/1998/C30/1.

23 ibid 4.

24 European Council (1999) Resolution on Youth Participation. OJ/1999/C42/1.

25 European Commission (2001). A New Impetus for European Youth - White Paper COM (2001) 681 final, 21 November 2001. 
policies, such as education and training, employment and social inclusion, health and antidiscrimination. ${ }^{26}$ On the basis of the four priority areas outlined in the White Paper, the Council established a framework for European co-operation in the field of youth. ${ }^{27}$

As a follow up to its 2001 White Paper, in October 2004 the Commission issued a Communication. ${ }^{28}$ The Communication served as a stocktaking exercise of the achievements of the framework at both the EU and the Member State levels. It demonstrates the considerable policy activism that had been achieved to date in the area of Youth Policy and its mainstreaming throughout the EU, particularly in other OMCs such as the EES, education, and social inclusion. Indeed the Communication argues that Youth Policy is governed by its own OMC, but that such an OMC is different because unlike other policy areas, the objectives remain qualitative and their implementation is not the subject of national plans of action coordinated at the European Level. ${ }^{29}$ To provide greater coherence and consistency to the various initiatives in the field of Youth Policy, the Council adopted the European Youth Pact in March 2005 as part of the revised Lisbon Strategy. ${ }^{30}$ The pact focussed on three areas: employment integration and social advancement; education, training and mobility; and the reconciliation of work and family life. The aims of the European Youth Pact were to be pursued within the EU's Lisbon Strategy and focus on the three previously mentioned OMCs. In this respect, the area of Youth Policy provides a good example of the practice of mainstreaming within the EU and the OMC mode of governance.

In response to the EU's New Social Agenda launched in 2008, the Commission launched in April 2009 its Communication 'Youth - Investing and Empowering'. ${ }^{11}$ The Communication represents one of the most detailed analyses of the current situation of young people across the EU and, for the period 2010-2018, invited both the Member States and the Commission to cooperate in the field of youth by means of a renewed OMC. It proposed a cross-sectorial approach with both short and long term objectives, involving all key policy areas that affect the EU's young people. The Communication also invited all Member States to organise a permanent and regular dialogue (structured dialogue) with young people. Furthermore, via its Communication the Commission also encouraged a more research and evidence-based youth policy. Following the Communication, the Council adopted the 2009 resolution on a renewed framework for European cooperation in the field of youth (2010-2018). ${ }^{32}$ The resolution defines one overarching objective, namely to enable all young women and men to make the best of their potential to be achieved via two subobjectives: 1) more and equal opportunities for young people in education and in the labour

26 ibid 18-21.

27 Resolution of the Council and of the representatives of the Governments of the Member States, meeting within the Council of 27 June 2002 regarding the framework of European cooperation in the youth field [2002] OJ C168/2.

28 'Communication from the Commission to the Council: Follow-up to the White Paper on a New Impetus for European Youth: Evaluation of Activities Conducted in the Framework of Cooperation in the Youth Field' COM (2004) 694.

29 ibid 7.

30 European Council Youth Pact [2005] OJ/2006/C70/1.

31 EU Commission Communication 'EU youth report. An EU strategy for youth - Investing and empowering. Commission staff working document accompanying the Communication’ [2009]SEC (2009b) 549 final, 17.

32 European Council (2009) Council Resolution on a renewed framework for European cooperation in the youth field (2010-2018) OJ [2009] C311/1. 
market; and 2) active citizenship, social inclusion and solidarity of young people. The objectives are underpinned by eight fields of action in which initiatives should be undertaken: education and training; employment and entrepreneurship; health and well being; participation; voluntary activities; social inclusion; youth and the world; and creativity and culture.

In addition to the 2009 Framework Resolution, the issue of youth is also part of Europe 2020, the vehicle taking forward the EU's policy commitments over the next decade. In Europe 2020 the area of youth is not only incorporated into the integrated policy guidelines that concern employment, education, training and skills, and social inclusion/poverty, ${ }^{33}$ but it forms one of the flagship initiatives. The seven flagship initiatives are jointly undertaken by EU and national actors and are steered by the European Commission - in the area of Youth the initiative is called 'Youth on the Move'. The focus of this initiative is to increase the chances of young people in finding a job by enhancing student and trainee mobility and improving the quality and attractiveness of education and training in Europe. ${ }^{34}$ Since this matches several of the action fields of the 2009 Framework Resolution (Education, employment and participation), it has essentially been incorporated into this wider structure and as such, further strengthens the political competence of the 2009 Framework Resolution. Furthermore, with young people being one of the worst affected by the economic crisis, political support for the EU to step up in this policy field continues. This is illustrated by the recent initiatives such as Youth on the Move and the Youth employment Package (including the Youth Guarantee), which are both part of wider EU strategies (Europe 2020 and the EES, respectively) and are incorporated in the EU Youth Strategy. ${ }^{35}$

In summary it can be said that the legal competence, i.e. the basis in the EU treaty for the development of an overall EU Youth Policy is small and limited. Despite this, its political competence is strong since it grasps momenta created in other EU policy fields and broader EU strategies, such as the EES, the Lisbon Strategy, the Laeken Declaration, the 2008 New Social Policy Agenda, and Europe 2020. Each of these addresses issues (employment, social inclusion, education and participation) that form the impetus of the 2009 Framework Resolution.

\section{INVENTORY OF EU YOUTH POLICY ACQUIS}

The above section makes clear that the 2009 Framework Resolution forms the core component of the EU's Youth Policy. Therefore we take this framework resolution as a starting point to identify the instruments that form the acquis communautaire of EU Youth Policy. In total we identified 101 instruments (overview is available on request) that were adopted between 1961 and 2010. Such instruments include directives, action programmes, resolutions and OMCs (see Figure 1). There is a relatively small group of instruments indicated as "other". This group contains instruments such as Council Conclusions,

33 European Council, Council Decision of 21 October 2010 on guidelines for the Employment policies of the Member States. (OJ [2010] L 308/46).

34 European Commission Initiative Youth on the Move: An initiative to unleash the potential of young people to achieve smart, sustainable and inclusive growth in the European Union. [2010] (Comm 2010/477 final).

35 European Commission Communication [2013a] COM/2013/477/final and European Commission Initiative [2013b] COM/2013/144/ final. 
Figure 1. Number and type of instruments in EU Youth Policy adopted over the course of time

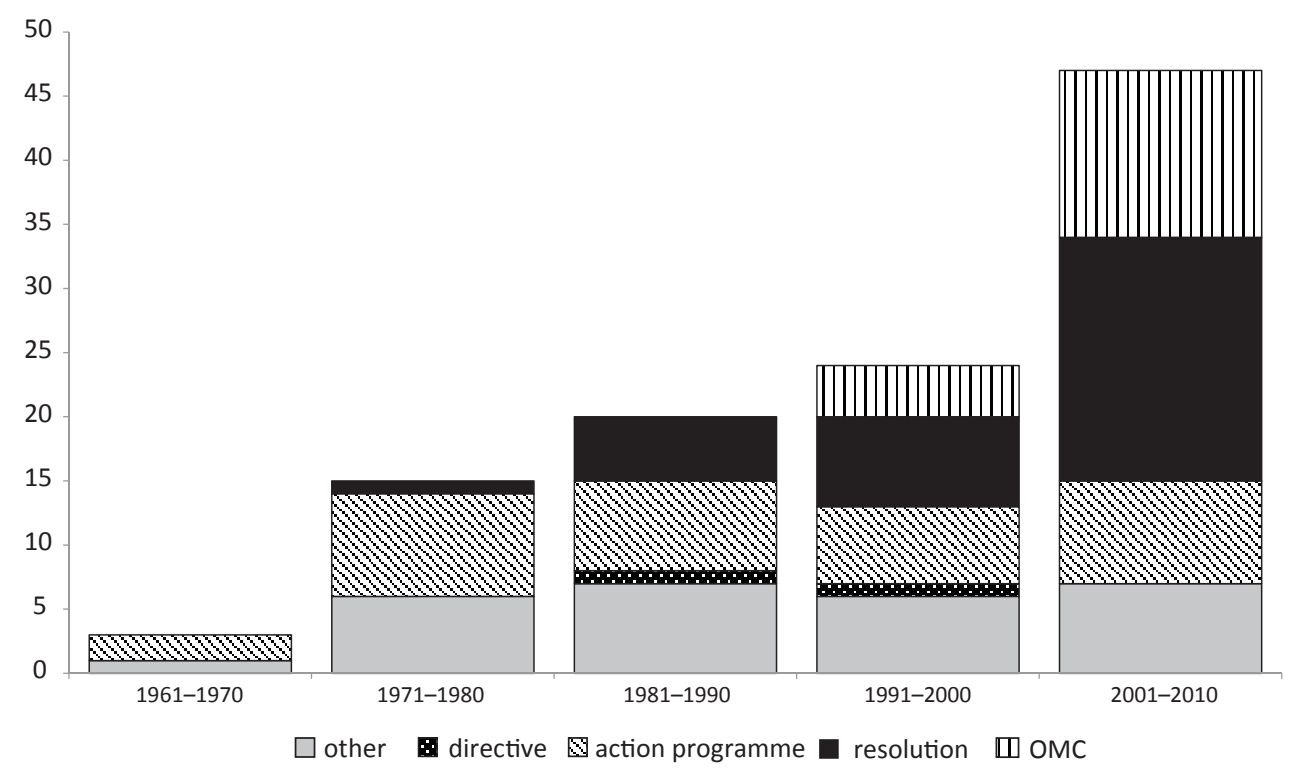

declarations, the decisions and regulations dealing with the European Social Fund and the two EU charters concerning fundamental rights (1989 for workers and 2000 for the EU).

Figure 1 provides an overview of the number and type of instruments in EU Youth Policy adopted for the period of analysis (from 1960s to 2010). ${ }^{36}$ Figure 2 gives an overview of EU Youth Policy activism in the eight fields of action of the 2009 Framework Resolution. The number of actions in this field is higher than the number of instruments in Figure 1. The deviation is a result of some instruments addressing more than one action policy and this is particularly the case of those instruments adopted during the last period of analysis (2000-2010). Together, Figures 1 and 2 reveal several traits within the field of EU Youth Policy. Generally speaking, over time, EU policy activism has increased, but most of that increase (approximately 50 per cent) occurred during the last period, 2000-2010. This increase resembles the political momentum EU Youth Policy gained during the second half of the 1990s and its consolidation in the renewed framework for 2010-2018. Furthermore, with the exception of two directives, Figure 1 reveals that the acquis communautaire of Youth Policy is comprised of legally non-binding measures. The two directives are both adopted in the action field 'health \& well-being' and concern health and safety at work - a social policy area that is predominantly governed by EU hard law. ${ }^{37}$ Looking more closely

36 The inventory also includes instruments from the period after 2010, however, since we decided to present the development in periods of ten years, the inclusion of this data in the figures is decisive in the sense that it only includes three years. In these three years, nine instruments have been adopted which continue the line of development that began in the first decade of 2000.

${ }^{37}$ Beryl Peter Haar and Paul Copeland, 'What are the Future Prospects of the European Social Model? An Analysis of EU Equal Opportunities and Employment Policy’ (2010) 16/3 European Law Journal 273-291. 
at the typology of EU instruments used in EU Youth Policy, we can see that over time, the variety of instruments increases from two in the 1960s (action programmes and a commission recommendation) to five in the $1990 \mathrm{~s},{ }^{38}$ and finally to a more representative variety of four instruments between 2001-2010. ${ }^{39}$

Figure 1 also demonstrates a shift in the typology of instruments used - during the first three decades (1961-1990) action programmes are the most popular instruments, while they become marginalised during the last period (2001-2010) in favour of Council Resolutions and OMCs.

\section{Figure 2. EU Youth Policy activism in eight fields of action}

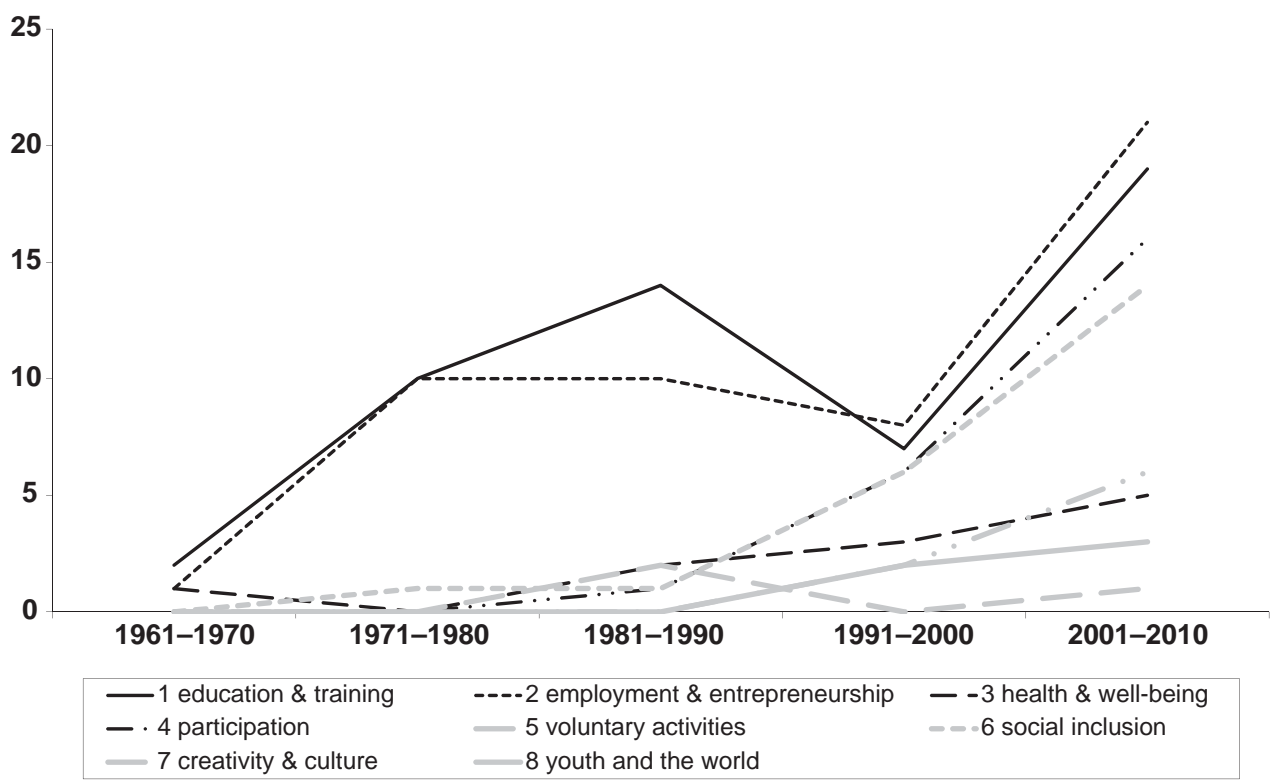

Figure 2 confirms the increase in EU Youth Policy activism in the last period (20002010), yet, it shows a significant difference in the intensity of policy activism. The action fields 'youth and the world' and 'creativity \& culture' lag considerably behind the other fields. Despite there being twice as much activity in the action fields 'health \& well-being' and 'voluntary activities', these two fields still demonstrate a relatively moderate level of activism compared to the action fields 'social inclusion', 'participation', 'education \& training' and 'employment \& entrepreneurship'. Only in the latter two action fields has the EU been considerably active all the time. The first one even demonstrates a remarkable upsurge of activism during the 1980s. This upsurge can be contributed to the successive action programmes (called: Petra) that concerned the preparation of young people for work and their transition from education to working life that started in 1976 and gained

38 This is due to the adoption of one of the two exceptional directives.

39 This variety would be more when the category 'other' were subdivided in specific instruments, however, the increasing number in this category could be considered as a signal for such. 
momentum in the 1980s when (youth) unemployment increased across the Member States. ${ }^{40}$ The last Petra programme was adopted in 1991, after which its main objective - having education and vocational training better attuned to the skills and needs of the labour market - was incorporated into the employment strategy.

With respect to the action field of social inclusion, it is worth noting that the EU has been active in this field since the 1970s. Such EU programmes rarely single out target groups, unless it is clear that a group is threatened by poverty or exclusion, such as migrants or children of families already living in poverty. Although young people are not named as a specific target group, the actions of the Member States targeting young people are supported by the EU poverty programme. As such, these programmes indirectly support youth policy and are an important aspect of EU Youth Policy. Despite this, we have only found evidence of this in relation to one programme ${ }^{41}$ and therefore confined the inventory to this programme only. Hence, it is only during the last period (2000-2010) that the policy field of combating social exclusion becomes tangible to the EU policy agenda. This development can be attributed to the Treaty of Nice, ${ }^{42}$ which clarified the competence of the EU in the field, and the Lisbon Strategy, which, as described above, included a social (cohesion) dimension in its new EU strategy for 2010. Consequently, the action field 'social inclusion' becomes more visible in EU Youth Policy and vice versa, resulting in a better streamlining of the problems of young people in social inclusion policies.

The strong increase of policy activism during the last period (2000-2010) in the action fields ‘education \& vocational training' and ‘employment \& entrepreneurship' can also be attributed to the Lisbon Strategy, as well as its re-launch in 2005 and its continuation in Europe 2020. Although both action fields have often been addressed together in the field of youth, this is even more so after 2000. A closer inspection reveals that of the nineteen activities in the action field 'employment \& entrepreneurship', two activities exclusively deal with this action field, while ten activities also include education, and seven include other action fields, among which four cover social inclusion.

Although the development of the action field 'participation' appears to keep pace with 'education \& vocational training' and 'employment \& entrepreneurship' in terms of policy activism, in fact it follows its own path of political development: EU citizenship. The 1999

40 Mixed Resolution concerning measures to be taken to improve the preparation of young people for work and to facilitate their transition from education to working life PETRA (OJ [1976] C308/1); Mixed Resolution concerning measures to be taken to improve the preparation of young people for work and to facilitate their transition from education to working life PETRA (OJ [1980] C23/1); Mixed Resolution concerning measures to be taken to improve the preparation of young people for work and to facilitate their transition from education to working life PETRA (OJ [1982] C193/1); Mixed Resolution extending for one year certain measures to be taken to improve the preparation of young people for work and to facilitate their transition from education to working life PETRA (OJ [1985] C328/3); 87/569/EEC: Council Decision concerning an action programme for the vocational training of young people and their preparation for adult and working life PETRA (OJ [1987] L346/31); Mixed Conclusion on the second European Community action programme (1982 to 1987) concerning the transition of young people from education to adult and working life PETRA (OJ [1988] C177/1); and 91/387/EEC: Council Decision amending Decision 87/569/EEC concerning an action programme for the vocational training of young people and their preparation for adult and working life PETRA (OJ [1991] L214/69).

41 Council Decision concerning a programme of pilot schemes and studies to combat poverty [1975] OJ L199/34.

42 Treaty of Nice [2001] OJ C80/1. 
resolution on youth participation makes it clear as it encourages the enabling of "young people to participate in all aspects of active citizenship, including their political participation and their mobility within the European Union, thereby involving young citizens in the process of further European integration". ${ }^{43}$ This action field serves two purposes: 1) to promote active participation of young people in societal matters; and while doing so 2) stimulate the inclusion of young people who are (threatened) by exclusion. As such, this action policy works both ways: it enhances active citizenship and reduces youth social exclusion. ${ }^{44}$ Moreover, it is therefore no coincidence that these two action fields kept pace with each other in the 1990s.

Finally, what stands out in both figures is that over the course of time the difference between the number of instruments adopted in the periods deviates substantially from the number of action fields addressed in that same period. Thus while this relates to the period $1961-1970$ as $3: 4$, it is $10: 12$ in the period $1971-1980,16: 22$ in the period 1981-1990, 22:30 in the period 1991-2000, and 45:80 in the period 2001-2010. As discussed in section 2 , the increase in activism and policy actions not only signifies the movement towards a genuine EU Youth Policy, it also indicates a growing coherence between the different fields of action. This can be deduced from the number of instruments that deal with actions on education, employment, participation and social inclusion, either by dealing with all four issues within one instrument, or a combination of instruments. In the final section we further examine the effect of this coherence in policy actions with respect to the incentives they create for action within the Member States.

\section{THE HYBRID STRUCTURE OF EU YOUTH POLICY}

It has been argued above that in contrast to the earlier piecemeal approach to the policy field, from the second half of the 1990s there exists more coherence between the eight action fields, as illustrated in Figure 2. An example of such coherence can be found in the 2004 Mixed Resolution on social integration with respect to young people that calls for the Member States "to take particular account of the measures appropriate in a social integration context to young people" and states that "it is desirable that there be more coherence, coordination and cooperation in the formulation of policies of a social nature, with particular regard to the youth sector". ${ }^{45}$ Policies addressed in this resolution include education, mobility, employment, and social integration. Furthermore, the resolution provides a nonexhaustive list of twelve measures to be considered by the Member States, involving the action fields social inclusion (measures i, ix, x, and xii), participation (measures ii and vii), education (measures iii, v, vi and xi), and employment (measure iv), whereas measure viii addresses all four of the action fields. Another example is the 'Youth in Action' programme (2007-2013) ${ }^{46}$ that replaces several separate programmes in the field of education, the programmes to encourage the exchange of young workers, and the 'youth for Europe' programmes. Furthermore, it emphasises in Article 11 its complementarity with 'other areas

43 European Council Resolution on Youth Participation [1999] OJ/1999/C42/1.

44 This bilaterally can also be found in the action programmes 'Youth for Europe'.

45 European Council Resolution of the Council and of the Representatives of the Governments of the Member States, meeting within the Council, on social integration with regard to young people [2004] (doc. 9601/04 of 18 May 2004).

46 European Council Decision Establishing the Youth in Action Programme for the period 2007-2013 [2006a] OJ/ 2006/L327/30. 
of Community action', among which education, employment, health, and social inclusion feature. ${ }^{47}$ The 2006 action programme 'Progress' is yet another example of the growing coherence since it underpins the EES and the OMC on social inclusion and stresses its consistency and complementarity "with other Union and Community policies, instruments and actions", among which are education, training and youth. ${ }^{48}$

As these examples demonstrate, the interaction between the action fields is more than just coherence. In this respect we conclude that from 2000 onwards, a hybrid structure of complementarity is created. The 2002 mixed resolution regarding the framework of European cooperation in the youth field is another example of such complementarity: it refers and builds on previous EU initiatives and promotes an integrated approach between these action fields. Moreover, by the explicit acknowledgement that instead of having independent policy fields, Youth Policy should be complementary to other policy fields, we argue that this resolution is the first step towards transformative hybridity. ${ }^{49}$ This means that certain thematic priorities of the specific youth field - participation; information; voluntary activities; and greater understanding and knowledge of youth - are to be governed by the OMC, and that the youth dimension should be taken into account in other policies as well, including education, lifelong learning, mobility, employment and social integration, combating racism and xenophobia, and autonomy.

With the interlude of the 2005 European Youth Pact, the 2009 renewed framework resolution for European cooperation in the field of youth finalises the merging into one new hybrid process. This merging consolidates the dual approach of the 2002 framework involving the development of EU Youth Policies by specific initiatives and the promotion of youth issues by mainstreaming them into other fields. Also, the renewed framework is more comprehensive than the 2002 framework and the 2005 Youth Pact, since it includes all eight fields of action and it takes stock of all activities that already have been undertaken by the EU. We deduce this from several aspects. First, as indicated in Section 2, it defines one overarching objective (to enable all young women and men to make the best of their potential) that is subdivided into two more specific objectives: 1) to create more and equal opportunities for all young people in education and the labour market; and 2) to promote the active citizenship, social inclusion and solidarity of all young people. With this the framework resolution merges the two main developments within the field of EU Youth Policy: that of education and employment which gained political momenta with the EES and the Lisbon Strategy; with that of participation and social inclusion which gained political momenta with the Laeken Declaration and the Lisbon Strategy.

Furthermore, the 2009 Framework Resolution deliberately and explicitly names the eight action fields concerning which a dual approach should be undertaken in order to achieve the two interrelated sub-objectives. First, specific initiatives should be undertaken in the youth field - i.e. "policies and actions specifically targeted at young people in areas such as non-formal learning, participation, voluntary activities, youth work, mobility and

47 European Council Decision Establishing the Youth in Action Programme for the period 2007-2013 [2006a] OJ/2006/L327/30.

48 European Council Decision Establishing a Programme for Employment and Social Solidarity [2006b] OJ/2006/L315/1.

49 European Council Resolution of the Council and of the Representatives of the Governments of the Member States, meeting within the Council, regarding the framework of European cooperation in the Youth Field [2002] OJ/2002/C168/2. 
information". ${ }^{50}$ Second, initiatives should be mainstreamed - i.e. "initiatives to enable a cross-sectoral approach where due account is taken of youth issues when formulating, implementing and evaluating policies and actions in other policy fields which have significant impact on the lives of young people". ${ }^{51}$

In fact, we deduce the aim of the 2009 Framework resolution to merge the action fields and policy initiatives in these fields also from the specific and mainstreaming initiatives listed in the Annex of the resolution that perfectly match the initiatives that have already been undertaken. More specifically, the framework resolution coordinates five different governance techniques supporting all EU Youth action fields: reporting, dissemination and monitoring; evidence-based policy-making; structured dialogue; mutual learning; and the mobilisation of funds. Youth work is in this context considered as a support to all fields and cross-sectoral cooperation is considered as an underlying principle. These governance mechanisms are in addition to the mechanisms that the individual EU initiatives regarding each specific action field create. Our analysis of the acquis communautaire on youth shows that this includes the following governance mechanisms to stimulate Member States to take EU Youth Policies into account:

- financial support (in particular by the European Social Fund);

- exchange of good practices,

- challenged (by peer reviews and benchmarks),

- persuaded (by progress reports and evaluations, but also

- by practical support (by the Commission), and

- forced via judicial review (by directives).

As a result of the political strategic merger of the action fields and the individual initiatives within these action fields, the various governance mechanisms, those supporting all the fields and those of the individual initiatives, have also merged. Hence, since they are applied within the same policy field, they work together for the same goals, within the same context simultaneously. As such they work to each other's strengths and together build pressure on the Member States to take youth matters into account when developing national laws and policies in the various action fields. Within the action field of employment and entrepreneurship for instance, eleven policy initiatives cover the field, which are governed by several integration instruments that employ different incentives and compliance mechanisms. Among the integration instruments we find the EES, two mixed resolutions, one mixed conclusion and a directive. Together these instruments hold a panoply of incentives, including financial support (Progress and ESF), support in learning by dissemination of information and practices, and practical support by the Commission. They also apply a whole range of compliance mechanisms, among which are monitoring and evaluations by the Commission, progress reports, and judicial review.

50 Article 3(i) European Council Framework Resolution on a renewed framework for European cooperation in the youth field (2010-2018) [2009] OJ C311/1.

51 Article 3(ii) European Council Framework Resolution on a renewed framework for European cooperation in the youth field (2010-2018) [2009] OJ C311/1. 


\section{CONCLUSION}

This article has focused on the interaction of the EU's OMC with other integration instruments, notably hard law and traditional soft law. Central to this analysis it has been to further understand the meaning of the OMC as an integration instrument. For this we chose the field of EU Youth Policy. While there is limited competence for the EU to act in this field, the historical analysis has shown that on the political level, the issue has grabbed its moments, which has resulted in a coherent programme addressing the issue of Youth from eight different policy angles.

This coherence is also found on the instrumental level in the 2009 framework resolution. Significant in this respect is the changing type of integration instruments to operationalise EU Youth Policy: from mainly action programmes to a wider range of instruments including policy guiding resolutions and OMCs. As the regulatory mechanism of the framework resolution, the OMC played an important role in creating this coherence, since it functions as a spinal-cord that connects the eight action fields. It does so on two levels: first, on a policy level by addressing the different action fields in relation to each other; and second, on an instrumental level by merging the different instruments used to further the integration of the different action fields in order to achieve the two main goals of the resolution.

The result of the merger of the policy goals and integration instruments is that each action field creates a stimulus package of positive incentives and compliance mechanisms to influence the activities of the Member States in the area of youth. Moreover, the iterative nature of the OMC has created a cycle of three years by which the objectives can be reviewed and the action priorities changed (a rolling agenda), enabling the EU Youth Strategy to continue its development and incorporate new initiatives within the basic structure.

A particularly interesting factor of the EU Youth Policy is that it illustrates that the OMC not only interacts with EU hard law, such as directives, yet it also interacts with soft law, among which we also find action programmes and policy guiding resolutions. Our analysis shows that the strength of the OMC lies not so much in its individual governance capacities, instead it lies in what it can create in its interaction with other integration instruments (coordination of governance). Although this will differ per policy field since it is also highly subjective to the political setting, however, what our study of EU Youth Policy illustrates is that when the political willingness is there, the EU can undertake a great amount, even when the legal possibilities are limited. In what it can create depends on the instruments the EU chooses. With the use of mainly action programmes (read: financial support), the EU achieved little more than piecemeal activities to address the situation of the young. The OMC on the other hand functioned as an amplifier merging in itself nonsignificant soft law integration instruments, into a significant coherent programme addressing the situation of young people. Moreover, as a result of this merger on a policy and instrumental level, a programme was developed that is underpinned by a wide variety of stimulus including incentives and pressures for Member States to comply with the programme when dealing with the subject on a national level.

More generally, in conclusion, what our study demonstrates is that in policy areas in which the EU has a limited competence, overtime OMC-type governance can make a significant contribution to both broadening and deepening integration within the field. 


\section{LITERATURE}

Armstrong, K., 'EU Social Policy and the Governance Architecture of Europe 2020’ (2012) 18/3 Transfer: European Review of Labour and Research 285-300.

Borrás, S. and Jacobsson, K., 'The Open Method of Co-ordination and New Governance Patterns in the EU’ (2004) 11/2 Journal of European Public Policy 185-208.

Búrca, G. de and Scott, J., Law and New Governance in the EU and the US (Hart Publishing 2006).

Haar, B. P. and Copeland, P., 'What are the Future Prospects of the European Social Model? An Analysis of EU Equal Opportunities and Employment Policy’ (2010) 16/3 European Law Journal 273-291.

Heidenreich, M. and Zeitlin, J. (eds), Changing European Employment and Welfare Regimes (Routledge 2009).

Laffan, B. and Shaw, C., 'Classifying and Mapping the OMC in Different Policy Areas' (2005) paper 02/D09 NEWGOV - New Mode of Governance.

Lange, B. and Alexiadou, N., 'New Forms of European Union Governance in the Education Sector? A Preliminary Analysis of the Open Method of Coordination’ (2007) 6/4 European Educational Research Journal 321-335.

Porte, C. de la and Pochet, P., 'Introduction', in Caroline de la Porte and Philipp Pochet (eds), Building Social Europe through the Open Method of Co-ordination (Peter Lang 2003).

Trubek, D. M. and Trubek, L. 'New Governance and \& Legal Regulation: Complementarity, Rivalry, and Transformation’ (2005) 13/3 Columbian Journal of European Law 595-622.

Velluti, S., New Governance and the European Employment Strategy (Routledge 2010).

Zeitlin, J., Pochet, P. and Magnussen, L. (eds), The Open Method of Co-ordination in Action (Peter Lang 2005). 